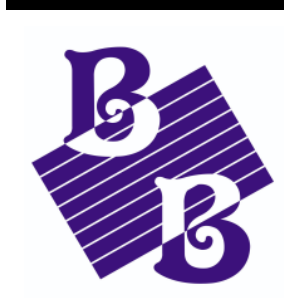

BioBacta

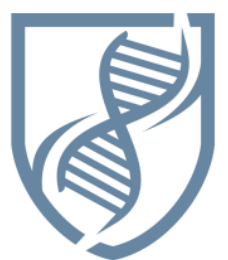

Journal of Bioscience and Applied Research www.jbaar.org

\title{
Understanding COVID-19, Genome, Epidemiology, Diagnosis, Treatment, and Vaccination
}

\author{
Eslam Mostafa ${ }^{1}$, Aisha El-Sawah*1, Esraa Magdy ${ }^{1}$, Ahmed Sayed ${ }^{1}$, Safaa El-Azab ${ }^{1}$, Ayman \\ Natei $^{1}$, Asmaa Husein' ${ }^{1}$, Salma Hassan', Menna Mostafa', Mohamed M. Omran ${ }^{3}$ \\ ${ }^{1}$ Biotechnology/Bimolecular Chemistry Program, Faculty of Science, Cairo University, Giza, Egypt \\ Giza, 12613, Egypt \\ 2 Molecular Biotechnology Program, Chemistry Department, Faculty of Science, Helwan University, Helwan, Egypt \\ Ain Helwan, 11795, Cairo, Egypt \\ 3 Chemistry Department, Faculty of Science, Helwan University, Helwan, Egypt \\ Ain Helwan, 11795, Cairo, Egypt \\ *Corresponding author: Aisha El-Sawah, Email: aishaelsawah0@gmail.com \\ Received: June 12, 2020. Accepted: July 20, 2020. Published: July 27, 2020
}

DOI: 10.21608/jbaar.2020.106102

\begin{abstract}
In December 2019, an acute respiratory disease called COVID-19 from the coronavirus family has spread in Wuhan city in China. Due to the fast transmission of this disease and the number of cases increase, it received the whole world's attention. And on 30 January 2020, the World Health Organization (WHO) officially announced that COVID-19 is epidemic. In March, WHO declared that it is pandemic due to the high number of cases confirmed globally. SARS-CoV-2, that has single-stranded (positive-sense) RNA with structural proteins (S, E, $\mathrm{M}, \mathrm{N})$, has common manifestations like dry cough, fever, and fatigue as the common cold. These symptoms range from moderate to severe that cause death, even there are also asymptomatic patients. The SARS-CoV-2 virus can be transmitted through person-to-person transmission. Though there are two different ways for its entry to the host cell, which are endosomal or plasma membrane fusion, both require ACE2 receptor attachment. There are different diagnostic techniques for SARS-CoV-2 ranging from RT-PCR and Immuno-tests to advanced methods such as CT and crisper technology. No therapies to COVID-19 have been developed so far, but researchers are currently working on developing therapies specific to this novel coronavirus. Furthermore, many of the repurposed drugs that have the potential to either attenuate the symptoms or prevent the viral entry/replication are still in preclinical and clinical trial phases. Besides the vaccination that has been developed whether they are live attenuated, subunit, or nucleic acid vaccines.
\end{abstract}

Keywords: COVID-19, Diagnosis, Epidemiology, Structure, Treatment, Vaccine 


\section{Background}

In December 2019, many cases of pneumonia appeared in Wuhan, Hubei province in China (Huang et al., 2020). The reason was quickly identified as an enveloped single-stranded RNA beta-coronavirus (Lu et al., 2020) that was named as severe acute respiratory syndrome coronavirus 2 (SARS-CoV-2), as it has a similarity in phylogeny to SARS-CoV (Zhu et al., 2020) and several bat coronaviruses (CoVs) (Zhou et al., 2020). Coronaviruses contain 4 genera: alpha $\mathrm{CoV}$, beta $\mathrm{CoV}$, gamma $\mathrm{CoV}$, and delta $\mathrm{CoV}$. In the recent 20 years, three CoVs have appeared that cause serious diseases, including the severe acute respiratory syndrome CoV (SARS-CoV) in 2002, Middle East respiratory syndrome $\mathrm{CoV}$ (MERS-CoV) in 2012, and now SARS-CoV-2 in 2019 (de Wit et al., 2016; D. Wang et al., 2020; WHO, 2019).

SARS-CoV-2 exhibits faster human-to-human transmission in comparison to SARS-CoV and MERS$\mathrm{CoV}$, thus leading to the WHO declaration of a worldwide public health emergency (Chan et al., 2020; N. Chen et al., 2020) and to be a pandemic on March 11, 2020 (Whitworth, 2020).

The receptor-binding domains (RBDs) for SARS-CoV is angiotensin-converting enzyme 2 (ACE2), while dipeptidyl peptidase 4 (DPP4) is the receptor for MERS-CoV (Li et al., 2003; Raj et al., 2013). SARS-CoV-2 has a similarity to $S A R S-C o V$ as it recognizes (ACE2) as its host receptor that binds to the viral S protein (Zhou et al., 2020). Thus, the RBD in SARS-CoV-2 S protein is crucial as it is the ultimate probable target for the development of vaccines, virus attachment inhibitors, and neutralizing antibodies (Tai et al., 2020a).

\section{Classification of Coronavirus}

They are related to the subfamily Coronavirinae in the family Coronaviridae and the order Nidovirales. Based on the genomic and phylogenetic structures, the (COVID-19) belongs to genera Betacoronaviruses (Fig.1). Human Betacoronaviruses which are (SARS-CoV, MERS$\mathrm{CoV}$, SARS-CoV-2) have many similarities and differences in their phenotypic and genomic structures that trigger their pathogenicity. The similarity between the (COVID-19) sequence and the SARS-CoV sequence, also the virus uses the ACE2 receptor as an entry receptor (Seah and Agrawal, 2020). According to these similarities, it was considered that the virus is SARS-CoV-2 (Cascella et al., 2020).
3. Coronavirus structure and genome structure

(COVID-19) or SARS-CoV-2 has singlestranded (positive-sense) RNA associated with a nucleoprotein within a capsid comprised of matrix protein, it possesses a spherical or pleomorphic envelope, the envelope carries club-shaped glycoprotein projections (Fig 2). Coronaviruses have large genomes (26.4-31.7 Kb). The GC content ranges from $32 \%$ to $43 \%$. ORFs are distributed among the various conserved genes. The genes of major structural proteins occur in the 5'-3' order as spike (S), envelope (E), membrane (M), and nucleocapsid (N) (Woo et al., 2010) (Fig 3). Coronaviruses have at least 6 ORFs in their genome. The first two ORFs (1a/b) are about twothirds of the length of the whole genome encode 16 non-structural proteins (nsp1-16). ORF1a and ORF1b have a frameshift in between resulting in the formation of two polypeptides which are: pp1a and pplab. These polypeptides are processed by virally encoded main protease (Mpro) or chymotrypsin-like protease (3CLpro) and one or two papin-like proteases into 16 non-structural proteins. SgRNAs of Covs is responsible for the translation of all structural and accessory proteins. The main structural proteins which are S, M, E, and N. On the one- a third of the genome near the 3'- terminus, the main structural proteins are encoded by ORFs 10, 11 (Czub et al., 2005; van Boheemen et al., 2012). Regarding these main structural proteins, different CoVs encode other special structural and accessory proteins, such as $4 \mathrm{a} / \mathrm{b}$ protein, and HE protein. These proteins are essential for the replication and maintenance of the virus (van Boheemen et al., 2012).

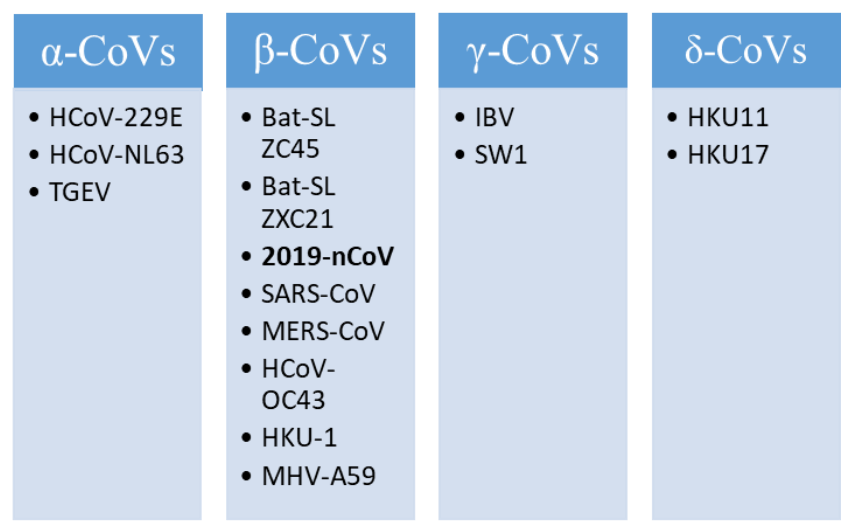

Fig.1. The phylogenetic classification of Coronaviruses with COVID-19 present in bold. 


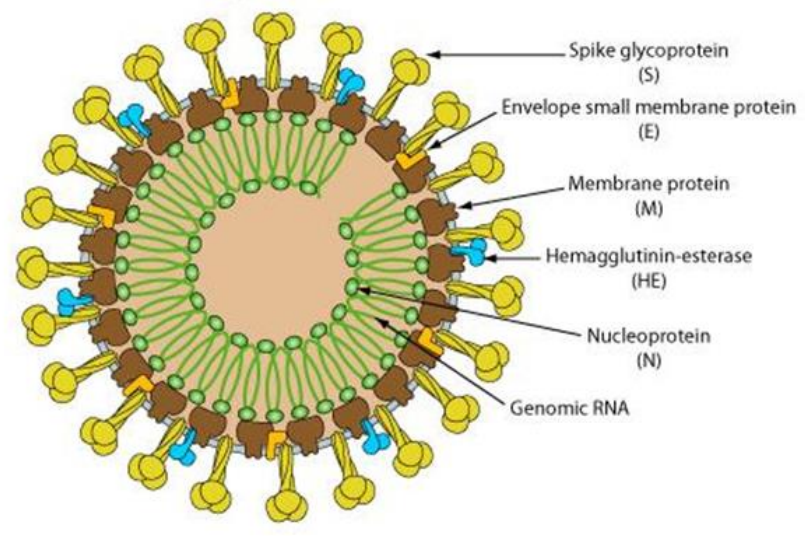

Fig.2. Structure of Coronavirus, this may be the shape of the new one COVID-19) (Mousavizadeh and Ghasemi, 2020)

$29903 \mathrm{bp}$

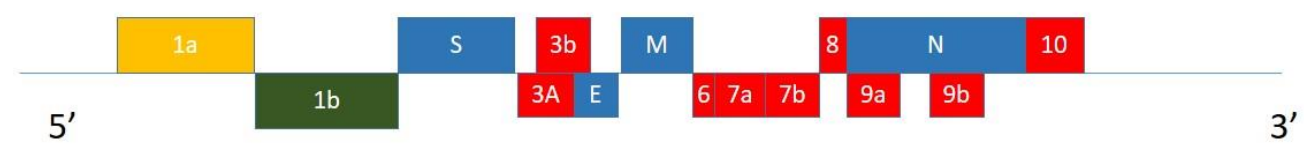

Fig.3. 5'-3' terminal sequence of SARS-COV-2 genome. The figure represents different ORFs, the order of the genome: ORF 1a/b, Spike (S), envelope (E), membrane (M), nucelocapsid (N). ORF 3ab, ORF6, ORF 7ab, ORF 8, ORF 9ab, and ORF10.

\section{Symptoms}

Coronavirus disease, that's called COVID-19, caused by one of the respiratory virus infections (SARS-CoV-2) has clinical manifestations, including fever, dry cough, fatigue or myalgia, shortness of breath, and pneumonia as dominant symptoms. Besides, some patients suffer from diarrhea, nausea, vomiting, headache, sore throat, and rhinorrhea (Guan et al., 2020; Leung et al., 2020; Tan et al., 2020; $\mathrm{H}$. Wang et al., 2020). The infection may develop into acute respiratory illness because of alveolar damage leading to progressive respiratory failure and even death (Xu et al., 2020). Different COVID-19 cases have mild or moderate symptoms, but some experience no symptoms (Kong et al., 2020). However, they can spread the virus (Leung et al., 2020; Peng et al., 2020). The virus RNA was identified in 30-min exhaled breath collection from a few patients who did not cough. This showed the possibility of SARS-CoV-2 transmission from asymptomatic individuals (Leung $\boldsymbol{e t}$ al., 2020).

\section{Transmission ways (Spreading)}

Most of the earliest contagious cases of SARSCoV-2 were due to the direct exposure to the Huanan seafood market (Li et al., 2020), but the exponential increase in infected individuals indicates that personto-person transmission is the main reason for this emergent virus outbreak (Peng et al., 2020). The transmission routes consist of direct transmission and contact transmission (Guan et al., 2020), whereas the direct transmission through a sneeze, cough, or respiratory droplets while the contact transmission through nasal, oral, or eye mucous membranes (Peng et al., 2020). This indicates different ways to the virus entry to the body, whether through the respiratory tract or eye exposure (Peng et al., 2020). SARS-CoV-2 transmission can also be through saliva and fecal-oral route (Peng et $\boldsymbol{a l}$. , 2020). Hence, using face masks could prevent coronaviruses transmission as they are detected in respiratory droplets (Leung et al., 2020).

The virus can bind to the ACE2 receptor either of human, cat, pig, or bat cells (Peng et al., 2020), but according to $\mathrm{CDC}$, there is no evidence that domestic animals can transmit the COVID-19 virus to humans. The ACE2 and SARS COV-2 high affinity make the populations with the highest ACE2 expression be at higher risk of the infection (Peng et al., 2020). In addition to individuals who are at advanced ages, who suffer from chronic medical conditions such as 
diabetes mellitus, cardiac failure, chronic kidney disease, asthma, or hypertension, or immunocompromised patients (Bhatraju et al., 2020; McMichael et al., 2020; Mimouni et al., 2020). Health care personnel and residents of care facilities are also at high risk for virus transmission and severe illness (McMichael et al., 2020).

\section{Mechanism of infection}

Studies have shown that the SARS-CoV-2 entry to ACE2 host cells requires the virus attachment, then membrane fusion (Ou et al., 2020; Tai et al., 2020b; Yan et al., 2020). The main route for the virus entry is through endosomal membrane fusion or endocytosis (Ou et al., 2020). SARS-CoV-2 Spike glycoprotein (S), which consists of two subunits, binds the ACE2 receptor through the S1 subunit, then mediates the membrane fusion by $\mathrm{S} 2$ subunit, but protease cleavage is necessary for the $\mathrm{S}$ protein fusion activation (Ou et al., 2020; Tai et al., 2020b; Yan et al., 2020). Hence, Lysosomal cathepsin $L$ is critical for priming the $\mathrm{S}$ protein to facilitate the SARS-CoV-2 entry (Ou et al., 2020). Trypsin which is an exogenous proteolytic enzyme can also show efficient $S$ protein activation and syncytium formation, but its absence does not prevent that syncytium formation $(\mathrm{Ou}$ et al., 2020; Xia et al., 2020). While the other pathway is through cell-cell fusion or plasma membrane fusion, that triggered by type II membrane serine proteases (TMPRSS), and that explains the SARS-CoV-2 rapid progress (Ou et al., 2020). For the endocytosis, phosphatidylinositol 3-phosphate 5-kinase (PIKfyve) and two-pore channel subtype (TPC2) is critical for the virus entry, as they are essential for early and late endosome formation, and lysosome, respectively $(\mathbf{O u}$ et al., 2020). The cell-cell fusion pathway is with higher efficiency than the endocytosis pathway for most viruses as the latter activates the antiviral immunity of the host cell (Xia et al., 2020).

SARS-CoV-2 showed a higher affinity to ACE2 receptors with 10- to 20-fold than SARS-CoV, which may illustrate the higher transmissibility and infectivity than of SARS-CoV (Xia et al., 2020). Studies have shown that the ACE2 receptor is highly expressed in lung alveolar cells of type II, the epithelial cells of the esophagus, ileum and colon absorptive enterocytes, urothelial cells of the bladder, proximal tubular cells of the kidney, myocardial cells, and the oral cavity cells especially in the tongue (Xu et al., 2020). That results indicate the high-risk organs for SARS-CoV-2 infection (Xu et al., 2020). So, The SARS-CoV viruses and ACE2 interaction show their infectivity potential factor (Vaduganathan et al., 2020).

\section{Epidemiology}

The outbreak began in Wuhan, China in December 2019 (Zhu et al., 2020). On 7 January 2020, the causative agent was discovered to be a novel beta coronavirus of the same subgenus as SARS-COV and named SARS-COV-2. Coronavirus disease 2019 (COVID-19) rapidly spread worldwide, with clinical manifestations ranging from mild respiratory symptoms to severe pneumonia (CDC, 2020). The breakthrough of the virus was in china and then it had transmitted to the neighbouring countries (Japan, Thailand, Republic of Korea). The first case had reported outside an Asian Continent was in America on 23 January 2020 (WHO, 2020v). The virus had appeared in the European Continent, where the first case had recorded in France on 26 January 2020 (WHO, 2020w), then in Germany on 29 January 2020 (WHO, 2020x), then in Italy on 31 January 2020 (WHO, 2020y), then in Spain, the United Kingdom and Sweden on 1 February 2020 (WHO, 2020z). The virus had appeared in Africa Continent, where the first case appeared in Egypt on 15 February 2020 (WHO, 2020a), then in Algeria on 26 February 2020 (WHO, 2020b). The first case had appeared in South America was in Brazil on 27 February 2020 (WHO, 2020c).

After the virus invaded the world, the number of new cases began to increase greatly, and the number of deaths increased daily. The number of cases raised to become 82294 confirmed cases globally. The testing criteria of centers for disease control and prevention has been updated to diagnose also severely ill persons for whom no cause had been known (CDC, 2020 ). A clinician asked to do testing for COVID-19 according to the new criteria of $\mathrm{CDC}$, testing the cases which have unexplained, severe pneumonia through obtaining oropharyngeal and nasopharyngeal swabs and sputum specimen to test for COVID-19. On 28 February 2020, it was reported by WHO that there were confirmed cases of COVID-19 in five new countries which are (Netherlands, New Zealand, Belarus, Lithuania, and Nigeria) (WHO, 2020d). The number of cases became 83,652 around the world. On 
29 February 2020, reports had revealed that there were two new countries added to the list which are (Mexico and San Marino). On this day, it was the first time since the start of the pandemic that the number of confirmed cases outside China exceeds the number of confirmed cases in China (WHO, 2020e). The number of total globally reported cases raised to $81,109,412$ new cases reported in China while 459 reported outside China (WHO, 2020e). By the end of February, the number of confirmed cases became 85,403 globally (WHO, 2020e).

On 1 March 2020, five new member states (Azerbaijan, Ecuador, Ireland, Monaco and, Qatar) reported cases of COVID-19. The number of confirmed cases became 87,137 globally and the number of deaths also increased to 2,977 globally (WHO, 2020f). On 2 March 2020, within a month of the first case being identified in Italy the number had grown to 1689, with 35 deaths (WHO, 2020g). On 8 March 2020, the number of reported cases globally raised to 105,586 (WHO, 2020h). On 11 March 2020, The World Health Organization defined Covid-19 to be a pandemic (WHO, 2020i). The Global pandemic invades all medical systems and the world, as the number of cases and deaths increased dramatically, at the forefront of these countries; Italy, Spain, Germany, and the United States of America. Where the crisis in Italy duplicated, and the number reached 12462 cases on 12 March (WHO, 2020j), and the cases expanded on 15 March to 21157 (WHO, 2020k) and continued to increase until 18 March to 31506 and the crisis worsened until the number of cases by the end of March became 101739 and the total number of deaths reached 11,591 (WHO, 20201). On the other hand, in one of the largest and most advanced countries in health care, the United States has not been freed out of this global epidemic. In just three days, from 21 March to $25 \mathrm{March}$, the number of patients had increased from 15,219 to 51,915 new cases (WHO, 2020m, 2020n) and this insane increase continued until it reached up to 85,228 cases on 28 March (WHO, 2020o).

At the end of March, the United States recorded the largest number of cases of coronavirus infection, passing China, which is the first country the virus had appeared in before Italy and the disaster struck and lost its balance as, on March 31, 2020, the total number of cases in the United States of America reached 140,640 cases and became the fifth country in the percentage of deaths after Italy, Spain, China and France (Fig.4) (WHO, 2020p). Through March 2020, 750,890 cases confirmed globally to be infected by COVID-19, 82,545 of the confirmed cases were in China with 3,314 deaths (WHO, 2020p).

On April 5, 2020, Spain topped the European continent in the total number of cases surpassing Italy, where the total cases have reached 124,739 cases. Globally, it exceeded the Million Barrier, as the total number of cases reached 1,133,758 cases and the number of deaths increased to 62,785 deaths (WHO, 2020q). On 10 April 2020, in Spain, the insignificant increase did not stop at this point, it recorded 152,446 total cases, while the United States remained the largest number of total cases in the world, recorded 425889 cases, and the total number of deaths increased to 14,665 (WHO, 2020r).

On 15 April 2020, the total number of cases globally continues to increase to reach $1,914,916$ cases and the number of deaths reaches 123,010. On the Asian continent, Iran topped the largest of total cases after China, where it reached 74,877 cases, while the number of deaths exceeded China, where it reached 4683 deaths. In Europe, Spain remained the largest number of total cases reaching 172,541 cases and the total number of deaths increased to 18,056 (WHO, 2020s). Despite the presence of Germany in the third position as the largest number of cases in Europe and the fourth in the world, but it recorded the lowest number of deaths compared to a large number of injuries in it that reached 127,584 cases and this is due to the quality of health care and its ability to maintain the situation (WHO, 2020s). On April 20 the number of cases increased globally to 2,314,621 new cases and the number of deaths increased to reach 157,847 deaths (WHO, 2020t). In just 10 days, on April 30, 2020, the number of total cases increased to nearly 700,000 as the number of cases reached 3,090,445 cases and the number of deaths increased to reach 217,769 (Fig. 5) (WHO, 2020u). April 2020 has the highest number of cases and deaths as shown in (Fig.6), which means the condition is getting worse (Fig. 6). 


$\begin{array}{cccccc} & \text { France } & \text { Germany } & \text { Spain } & \text { Italy } & \text { USA } \\ & & & & & \\ \text { Total Cases } & 39,642 & 57,298 & 78,797 & 97,689 & 122,653 \\ \text { Total Deaths } & 2,602 & 455 & 6,528 & 10,781 & 2,112\end{array}$

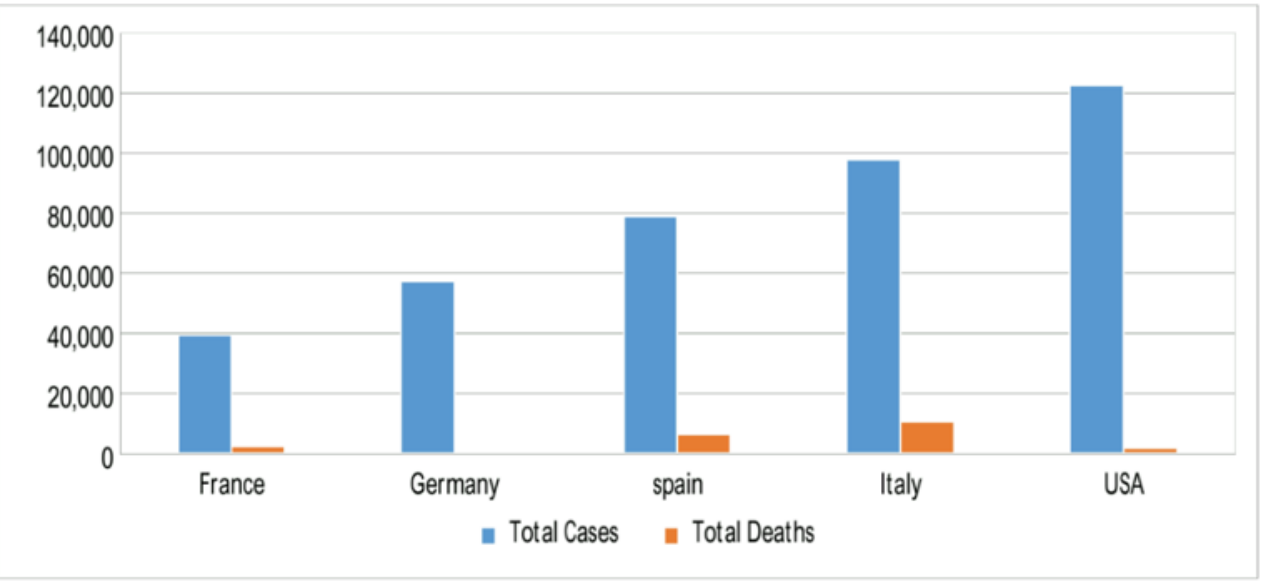

Fig.4. On 30 March 2020 as the figure shows, the USA recorded the largest number of total cases of Covid-19 then Italy then Spain then Germany then France.

$\begin{array}{llllll} & \text { UK } & \text { Germany } & \text { Italy } & \text { Spain } & \text { USA } \\ \text { Total Cases } & 165,225 & 159,119 & 203,591 & 212,917 & 1,003,974 \\ \text { Total Deaths } & 26,097 & 6,288 & 27,682 & 24,275 & 52,428\end{array}$

\begin{tabular}{|c|c|c|c|c|c|}
\hline \multicolumn{6}{|l|}{$1,200,000$} \\
\hline \multicolumn{6}{|l|}{$1,000,000$} \\
\hline \multicolumn{6}{|l|}{800,000} \\
\hline \multicolumn{6}{|l|}{600,000} \\
\hline \multicolumn{6}{|l|}{400,000} \\
\hline \multicolumn{6}{|l|}{200,000} \\
\hline & Uk & Germany & Italy & Spain & USA \\
\hline & & - Total Cases & | Total Deaths & & \\
\hline
\end{tabular}


Fig.5. On 30 April 2020, as the figure shows, the USA recorded the largest number of total cases of Covid-19 then Spain then Italy then Germany then the United Kingdom.

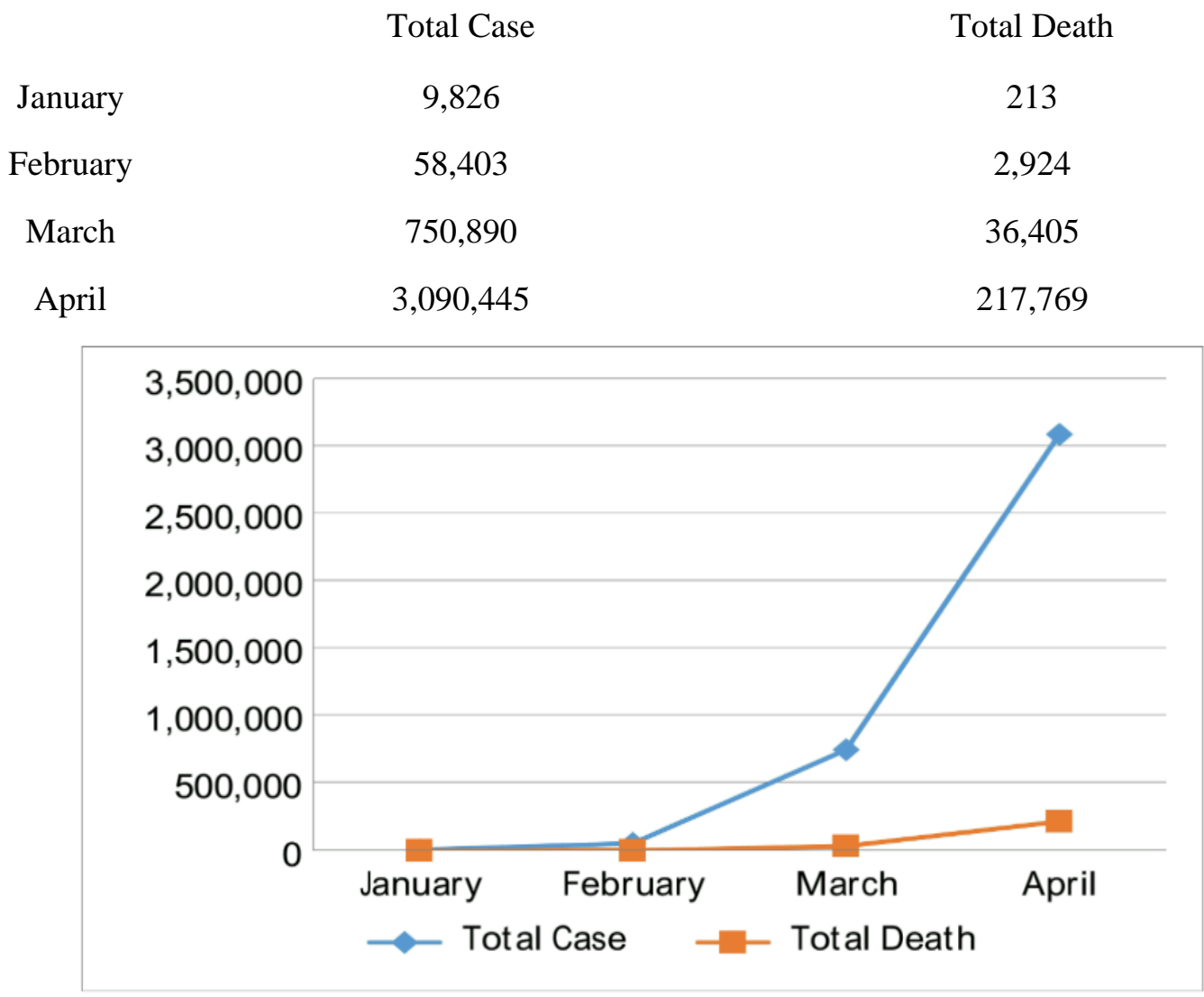

Fig.6. The graph is showing the total number of cases and deaths in the first four months April has the highest number. 


\section{Diagnosis}

\section{Clinical Diagnosis}

Early detection of global pandemic COVID-19 cases requires high availability of diagnostic testing to hold the emergence of this rapidly spreading, severe illness. In a few countries, the use of diagnostic tests on a wide scale has been a cornerstone of successful containment strategies. Although there is a different diagnostic technique of Real-time reverse transcriptase-polymerase chain reaction (RT-PCR) performed on respiratory specimens are the gold stander for COVID-19 diagnostic testing, other diagnostic methods are being developed and evaluated (Sheridan, 2020).

\subsection{Real-time reverse-transcription PCR}

For the diagnostic tests for SARS-CoV-2, CDC recommends collecting an upper respiratory specimen. The nasopharyngeal specimen is the preferable choice for swab-based SARS-CoV-2 testing, but oropharyngeal, mid-turbinate, or anterior nares samples also are acceptable alternatives (Control and Prevention, 2020; Zou et al., 2020). Respiratory samples should be obtained by using a flocked swab (which is made with an aluminium or plastic shaft) to improve the collection and release of cellular material. Swabs that contain calcium alginate, cotton, wood should be avoided, because they may contain materials that inhibit PCR testing. Swabs should be transferred immediately after sample collection into a universal transport medium to preserve the viral nucleic acid. Samples took from sputum, endotracheal aspirates, and broncho-alveolar lavage also should be sent directly to the microbiology laboratory for processing, and they may have greater sensitivity than the upper respiratory tract specimens (W. Wang et al., 2020). After collecting the specimen, samples undergo RNA extraction, then qualitative RT-PCR for target detection. PCR is the current reference test for the diagnosis of the infectious agents, and its advantage that the production of primers required for such tests occurs just after the sequence of the virus is known. The viral genome sequence was published on 10 January by the online resource virological.org (Wuhan-Hu-1, GenBank accession number MN908947 (Zhang, 2020), On 12 January, there are four other genomes added to the viral sequence database curated by GISAID.
Reverse transcriptase RT-PCR assay uses viral RNA extracted from patient samples, and synthesis complementary DNA (cDNA) by the reverse transcriptase enzyme and amplify target sequences of the viral genome from the template cDNA. r RT-PCR is a semi-quantitative tool, which can amplify the target sequence in a high speed depending on the concentration and quality of RNA of the virus in the sample (Corman et al., 2020).

The first quantitative reverse-transcriptasebased PCR (RT-PCR) test for SARS-CoV-2 detection was occurred in January by the WHO, just after the identification of the virus. Tests require from 4 to 6 hours to be completed. And the kit contains PCR primer-probe sets, which target the SARS-CoV-2 RNA-dependent RNA polymerase (RdRP) and envelope (E) genes (Corman et al., 2020). In the United States, the US CDC opted to develop its own SARS-CoV-2 assay test instead of adopting the WHO test. The PCR primer-probe target is the viral nucleocapsid gene (N1 and N2), and the human RNase $\mathrm{P}$ gene for affirmation that the RNA extraction succeeds. The analytic sensitivity and specificity for SARS-CoV-2 are high in both assays, with negligible cross-reactivity with other strains of coronaviruses, and the cycle threshold of both of them is less than 40 as criteria for positive results.

The two one-step quantitative RT reverse PCR tests have been developed by scientists at the Hong Kong University, which target the open reading frame $1 \mathrm{~b}$ (ORF1b) and the $\mathrm{N}$ regions of the viral genome depended on the first sequence deposited at GenBank (Accession number: MN908947) (Zhang, 2020); these two tests have been proved by using clinical specimens obtained from two patients infected with SARS-CoV2. The tests are required for the identification of multiple viruses in the SARS beta-coronaviruses subgenus to which include COVID-19. As no other SARS beta-coronaviruses are known to be circulating in humans, a positive test used for confirmation of infection with SARS-CoV-2 or a relative animal virus. The $\mathrm{N}$ gene assay is recommended as a screening test and the ORF1b test is recommended as a confirmatory test. The target primer and probe sequences for the ORF1b gene assay are:

Forward primer 5'-TGGGGYTTTACRGGTAACCT3', 
Reverse primer 5'-

AACRCGCTTAACAAAGCACTC-3'

Probe in 5'-FAM/ZEN/3'-IBFQ format 5'-

TAGTTGTGATGCWATCATGACTAG-3'

Whereas the primer and probe sequences for the $\mathrm{N}$ gene assay are:

Forward primer 5'-

TAATCAGACAAGGAACTGATTA-3'

Reverse primer 5'-CGAAGGTGTGACTTCCATG-3'

Probe in 5'-FAM/ZEN/3'-IBFQ format 5'GCAAATTGTGCAATTTGCGG-3'.

The predicted amplicon size of ORF1b is $132 \mathrm{bp}$ and 110 bp for $\mathrm{N}$ gene. (Chu et al., 2020)

\subsection{Point-of-care (POC) testing}

Low-complexity, rapid (as results appear within 1 hour) molecular diagnostic tests for respiratory viral infections that are Clinical Laboratory Improvement Amendments (CLIA) waived (Tests which FDA approved for home use (outside the laboratory) by non-laboratory personnel) (A. Hogan $\boldsymbol{e t}$ al., 2018). Abbott ID NOW COVID-19 is a Point-ofcare PCR isothermal test that submits a positive result is obtained within five minutes while a negative result is obtained within thirteen minutes (Sheridan, 2020).

\subsection{Serological and antigen tests}

Serological tests, using enzyme-linked immunosorbent assays (ELISA), are blood-based tests that used to detect the existence of coronavirus antibodies in a whole blood, serum, or plasma sample. These tests can identify individuals who have developed coronavirus antibodies (The Johns Hopkins Center for Health Security, 2020 ).

\subsubsection{Types of serology assays}

The rapid diagnostic test is a qualitative test (positive or negative) that can be used in POC tests and it requires a blood sample, nasal swab fluid, or saliva sample. This test is used to detect patient antibodies (IgM and $\operatorname{IgG}$ ) or viral antigen; it takes from 10 to 30 minutes (The Johns Hopkins Center for Health Security, 2020 ). Monoclonal antibodies against SARS-CoV-2 nucleocapsid protein have been produced, which might form the basis of a future rapid antigen detection test (Sheridan, 2020).

\section{A. Enzyme-linked immunosorbent assays (ELISA)}

It can be used as a qualitative and quantitative test that may be less complex than molecular tests, usually use whole blood, plasma, or serum spacemen from patients. The test depends on a plate which is coated by a viral protein, such as Spike protein, it takes from 1 to 5 hours (The Johns Hopkins Center for Health Security, 2020 ). Positive results show that the patient sample contains antibodies against coronavirus CoV-2, however, negative results wouldn't exclude the infection, as the antibodies production as an immune response against the viral infection takes days to weeks so in case of recent infection the test may give negative result (Guo et al., 2020).

\section{Limitations}

Both PCR and immunoassay technologies are not ideal for diagnosis techniques, although PCR tests are extremely accurate and its speed can be developed, they are complex to use and slow to show a result. Immunoassays are lower in accuracy and require more time to develop, however, they are easy to use and show results from 20 to 60 minutes (Sheridan, 2020).

\section{B. Antigen strip technique (Respi-Strip)}

A Test strip for the diagnosis of COVID-19 had been recently used that tool had been one of stooping COVID-19 spread. This test type is immunochromatic type where it detects where a substance is present or not (Kogaki et al., 2005). It has many advantages, the most important one is that it is a rapid where within 15 minutes you can get the result. Furthermore, it is reliable and less expensive than other molecular techniques (Vandenberg, 2020).

Not only this but also scientists found that the early usage of this strip will help the molecular doctors to quickly identify and determine the limits of the spread and so limit the number of the patients to reach severe illness from such a virus. It had a less userfriendly protocol than other gold techniques needed to be mentioned that both reagents and materials are easy to be found for such tests so mainly poor countries could depend on it as one of the first lines of detection 
and thus limits the tests done using RT-PCR. At the first stage (laboratory stage) during the development of the strip they had undergone two-phase to study and check both sensitivities and specify of this new strip then they break through the real patient samples to detect such properties. They found that the strip is more sensitive if the patient that used it has a high viral infection than others. According to this study that they had made, they found in high viral infection patients $7 / 10$ and in fewer ones was $6 / 10$ giving accrue and correct results. This test needs a sample as a nasopharyngeal swab, and it seems like a long Q-tip that begins from the patient nostril and extends and end near to the patient's ear. (Di et al., 2005).

This antigen test depends mainly on the protein of the virus, from older researches done on SARS-COV-1, so from this test disadvantages that such test couldn't recognizethe differe nce between SARS-COV- 1 \& SARS-COV-2, also there is no study for the reactivity done between beta coronaviruses genus and that of MERS samples, any delayed after with drawal it as it may affect its sensitivity (Blaschke et al., 2019), also scientists found that there is an error while reading the weak positive results from the strip and that is because the tube design and the line of the antigen detection is close to its end, in some cases lab technician needs to open the closed tube to recognize the strip better and that is wrong according to the biosafety levels but research and development are going on improving such cases. Last but not least recognized disadvantage that they had done this on the patient while the virus was less in strength and shedding so outpatients' samples may get fewer results, so they are trying to test the strip reproducibility after those changes (Vandenberg, 2020). This test is an immunochromatographic test (ICT) test that depends on a membrane technology that had colloidal nanoparticles made of gold and with the help of monoclonal antibodies to direct either SARS-COV 1 and 2 which had the nucleoprotein antigen against it (Vandenberg, 2020). The strip itself contains Plastic sheath where it's coated with nitrocellulose with gold colloidal nanoparticles that are located on a conjugated pad, the strip works as an antibody-antigen reaction where it contains anti-SARS-COV antibody steeled on a nitrocellulose part and then migration occurs between both buffer and sample with the designed anti-SARSCOV antibody. Other monoclonal antibody made to react with gold nanoparticles, that depend on the immobilization of the conjugate on the pad (Vandenberg, 2020).

The protocol of operation this strip is multistep one first collect the sample mainly (NPA) or (NPS) in the tube, then put LY-s buffer which is the dilution buffer mentioned from the company, to reach the ratio written in the manual then add the reagent used to stop the reaction at the cap of the tube, by stirring you are able to homogenize the preparatory tube, open the tube and immerse your strip for detection after 15 minutes you can get the result (Vandenberg, 2020). The result may appear in one of two ways, either positive or negative in negative result only one line appears at the upper part (Control), reddish-purple line, but at the positive tests, 2 lines appear the control line as mentioned in negative test in addition to another line in the test band (T). For patients suffering from cystic fibrosis, false-positive results should have appeared due to high viscosity and the huge pathogenic rate that they are suffering from, so those patients are showing an exception point but until now there is no full agreement to except them but the only precaution is given to take care of the sputum during withdrawing the samples as if there is sputum so false result will be expected; Overall specifici ty reaches $99.5 \%$ and PPV reaches $98.7 \%$ for the antigen positivity results, and if the patient that had any of the symptoms they need to undergo CT-scann ing and withdraw a PT-PCR sample to confirm our negative result (Vandenberg, 2020).

\subsection{Computed Tomography}

Going through the medical ways of an imaging method for COVID-19 diagnosis CT (computed tomography) is the most common way to give both quick and errorless results for COVID-19. The sensitivity of CT was analyzed to be much better than RT-PCR and may range from (80 to $90 \%$ ), on the other side, specificity is much low varied from (60 to 70\%) (W. Wang et al., 2020). CT was described include ground-glass opacities (GGO), crazy paving appearance, air space consolidation, bronchovascular thickening, and traction bronchiectasis (Zou et al., 2020). Finding GGO or GGO with consolidation was found more standard in the COVID-19 pneumonia patients, whereas the finding of consolidation was more frequent in non-COVID-19 pneumonia one's (Zhang, 2020). According to the study held by 
Chunqin Long et al, it was founded that the distribution of the lesions in the patients with confirmed COVID19 pneumonia was as shown: that the right lower lobe percentage and the left lower lobe was $(72.2 \%) \&$ $(66.7 \%)$ respectively, while the left lower lobe and the left upper lobe was found to be $(66.7 \%) \&(55.6 \%)$ respectively, and as for the right middle lobe and the right upper lobe $(55.6 \%) \&(52.7 \%)$ respectively, while the distribution patterns were found to be: peripheral distribution and central distribution of percentages $(72.2 \%) \&(27.8 \%)$ respectively. The majority of patients had more multiple CT abnormalities measured to be (69.4\%) (Long et al., 2020).

\subsection{Other advanced techniques}

The less well-known device is a device specifically designed for detection that combined both machine learning and virus detection. Artificial Intelligence (AI), an AI-based CT assessment that will be a promising technology in the future. They are trying to build typical AI algorithms that will be able to detect COVID-19 in chest computed tomography (S. Wang et al., 2020). As for the tracks made, the work of Gozes et al., Published on March 10, 2020, reveals a $98.2 \%$ sensitivity, but also a remarkable specificity that detects $92.2 \%$ for the deep learning-based thoracic algorithm (Gozes et al., 2020). One of the most advanced techniques that could be also used for diagnosis of COVID-19 is CRISPER which requires many steps to complete and it includes three steps, isothermal amplification, detection of virus RNA using Cas13, reading out using lateral flow dipstick. In the case of isothermal amplification, DNA should be extracted with high purity as qRT-PCR assays, two targets will be selected in the COVID-19 genome, the $\mathrm{S}$ gene, and Orf1ab gene. LwaCas13a CRISPR and RPA amplification primers guide RNAs that were designed for specific detection. Hence to increase the specificity of the assay during the step of detection of RNA virus, after Step (2), add 80ul of HybriDetect Assay Buffer to each 20ul reaction and mix well. Put the diluted reaction in a tube rack at room temperature. Add a HybriDetect Dipstick into each reaction tube and wait for the reaction to flow through the dipstick. Positive control samples should give two lines and negative control samples should only give the bottom line. For each test sample, check to see in (Fig.7) there are two lines appear for both $\mathrm{S}$ and Orflab genes, indicating a positive COVID-19 result (F. Zhang $\boldsymbol{e t}$ al., 2020).

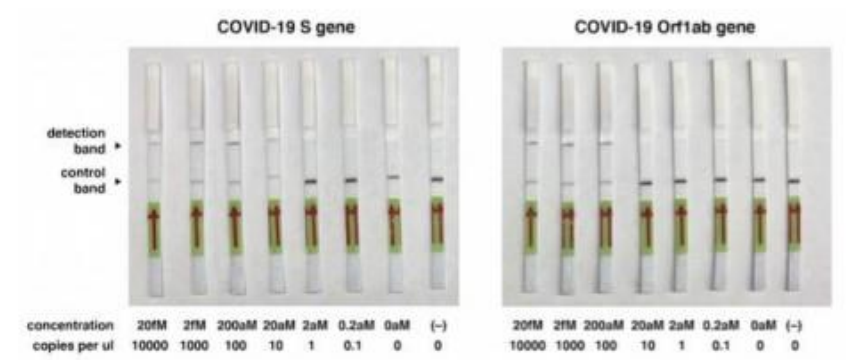

Fig.7. CRISPER Diagnostics - COVID-19 (F. Zhang et al., 2020) 
Table 1

List of all the analyzed laboratory changes that occur in severe or fatal COVID-19 patients. PCT: Procalcitonin, IL: Interleukin, CPR: C-relative protein (Henry et al., 2020).

\begin{tabular}{|l|l|}
\hline Biochemical Markers & Change occurs via laboratory test \\
\hline Albumin & Decrease \\
\hline Alanine aminotransferase & Increase \\
\hline Aspartate aminotransferase & Increase \\
\hline Total bilirubin & Increase \\
\hline Blood urea nitrogen & Increase \\
\hline Creatinine & Increase \\
\hline Creatine kinase & Increase \\
\hline Lactate dehydrogenase & Increase \\
\hline Myoglobin & Increase \\
\hline Creatine kinase- MB & Increase \\
\hline Cardiac troponin I & Increase \\
\hline Coagulation Markers & \\
\hline Prothrombin time & Increase \\
\hline D-dimer & Increase \\
\hline Hematology Markers & \\
\hline WBC & Increase \\
\hline Neutrophil count & Increase \\
\hline Platelets count & Decrease \\
\hline Hemoglobin & Decrease \\
\hline Eosinophil count & Decrease \\
\hline Lymphocyte count & Decrease \\
\hline Inflammatory biomarkers & \\
\hline Interleukin -2R & Increase \\
\hline Interleukin -6 & Increase \\
\hline Interleukin -8 & Increase \\
\hline Interleukin -10 & Increase \\
\hline PCT & Increase \\
\hline Serum ferritin & Increase \\
\hline Erythrocyte sedimentation rate & Increase \\
\hline CPR & Increase \\
\hline & \\
\hline
\end{tabular}


Table 2

Examples of commercial rapid tests for SARS-COV-2 (Sheridan, 2020)

\begin{tabular}{|c|c|c|c|c|}
\hline Producer & Name of Test & Characterization & Technology used & Duration of the test \\
\hline Abbott & $\begin{array}{l}\text { ID NOW'M } \\
\text { COVID-19 }\end{array}$ & $\begin{array}{l}\text { Rapid POC test, targeting } \\
\text { the coronavirus (COVID- } \\
\text { 19) RdRp Gene. }\end{array}$ & $\begin{array}{l}\text { PCR } \\
\text { isothermal } \\
\text { amplification }\end{array}$ & $\begin{array}{l}\text { Five minutes for } \\
\text { positive result and } \\
\text { Thirteen minutes for } \\
\text { negative result }\end{array}$ \\
\hline $\begin{array}{l}\text { Bio- } \\
\text { Medomics } \\
\text { Becton } \\
\text { Dickinson }\end{array}$ & $\begin{array}{l}\text { test for IgM- } \\
\text { IgG antibodies } \\
\text { against } \\
\text { Coronavirus }\end{array}$ & $\begin{array}{l}\text { Detects anti-viral } \\
\text { antibodies }\end{array}$ & Serological & $\begin{array}{l}\text { Within ten-to-fifteen- } \\
\text { minute }\end{array}$ \\
\hline Cellex & $\begin{array}{l}\text { qSARS-CoV-2 } \\
\text { IgG/IgM } \\
\text { Rapid Test }\end{array}$ & $\begin{array}{l}\text { Lateral-flow } \\
\text { chromatographic } \\
\text { immunoassay that detects } \\
\text { anti-viral antibodies }\end{array}$ & Serological & $\begin{array}{l}\text { from fifteen to twenty } \\
\text { minutes }\end{array}$ \\
\hline Cepheid & $\begin{array}{l}\text { Xpert Xpress } \\
\text { SARS-CoV-2 }\end{array}$ & $\begin{array}{l}\text { Runs on GeneXpert } \\
\text { benchtop system }\end{array}$ & PCR & Within 2 hours \\
\hline $\begin{array}{l}\text { Hangzhou } \\
\text { Testsealabs } \\
\text { Biotechnology }\end{array}$ & $\begin{array}{l}\text { One Step } \\
\text { Rapid test }\end{array}$ & $\begin{array}{l}\text { Rapid chromatographic } \\
\text { immunoassay for the } \\
\text { qualitative detection of } \\
\text { antibodies (IgG and IgM) } \\
\text { to COVID-19 virus }\end{array}$ & Serological & $\begin{array}{l}\text { Within fifteen to } \\
\text { twenty minutes }\end{array}$ \\
\hline Luminex & $\begin{array}{l}\text { ARIES SARS- } \\
\text { CoV-2 Assay }\end{array}$ & $\begin{array}{l}\text { Multiplex PCR test that } \\
\text { runs on the automated } \\
\text { ARIES system }\end{array}$ & PCR & Within 2 hours \\
\hline $\begin{array}{l}\text { Thermo } \\
\text { Fisher } \\
\text { Scientific }\end{array}$ & $\begin{array}{l}\text { TaqPath } \\
\text { COVID-19 } \\
\text { Combo Kit, } \\
\text { RT-PCR CE- } \\
\text { IVD Kit }\end{array}$ & $\begin{array}{l}\text { Assays cover the } \\
\text { complete sequence length } \\
\text { that is currently available } \\
\text { through the GISAID } \\
\text { Initiative }\end{array}$ & PCR & Within 2 hours \\
\hline
\end{tabular}




\section{Treatment of COVID-19}

No therapies to COVID-19 have been developed so far but based on already knowing the structure and mechanism of infection of SARS-COV2 researchers are currently working on developing therapies specific to this novel coronavirus. Needless to say that the process of developing a new therapy takes much time and labor to pass the many standard steps till finally being FDA-approved and prescribed, and that's why researchers try to make use of already existing FDA-approved broad-spectrum antiviral or repurposed drugs that have the potential to either attenuate the symptoms or prevent the viral entry/replication in COVID-19 patients $(\mathbf{L i}, \mathbf{2 0 2 0})$.

As for the therapeutic approaches, there are many of them in preclinical and clinical trial phases, but here are the latest most emerging ones:

Chloroquine/hydroxychloroquine with azithromycin FDA- approved for treating and preventing disease (e.g. malaria and other autoimmune diseases)They block the viral entry into the cells through inhibiting glycosylation of host receptors, proteolytic processing, and endosomal acidification (Vincent et al., 2005). In COVID-19 cases clinical trials, they showed improved radiologic findings, enhanced viral clearance, and reduced disease progression (Gautret et al., 2020), thus on March 26, 2020, The Taiwan CDC has announced hydroxychloroquine an important anti-SARS-CoV-2 agent. Moreover, on March 28, 2020, Food and Drug Administration (U.S Food and Drug Administration (FDA)) has stated an authorization of Emergency Use (oral formulations of hydroxychloroquine sulfate and chloroquine phosphate is given to the Strategic National Stockpile in order to treat adult and adolescent COVID-19 patients in hospitals when a clinical trial is not feasible nor available) (U.S Food and Drug Administration (FDA), 2020). Further studies are needed to evaluate the efficacy and mechanism of inhibition of such a drug.

Remdesivir: It simply targets the viral RNAdependent RNA polymerase (RdRp) and evades proofreading simultaneously by viral exoribonuclease, which results in the termination of the transcription of viral RNA (Agostini et al., 2018). Currently, The (U.S Food and Drug Administration (FDA)) has approved remdesivir for compassionate use, which means that patients with severe COVID-19 disease only are approved for this treatment (Live Science, 2020). Requirements to receive remdesivir may be less strict in other countries. Lopinavir and Ritonavir: The antiviral drug, which is a combination of ritonavir and lopinavir, at first generated excitement among researchers. Afterward, new data from China, published on March 18, 2020, could not detect a benefit when the drug was taken by patients (Cao et al., 2020).

Baricitinib, sold as a prescription drug called Olumiant: This drug is already approved for rheumatoid arthritis treatment. Recently, thanks to the artificial intelligence application to create drugs faster, it has been reported that Baricitinib is a possible treatment for COVID-19 with both anti-viral and antiinflammatory properties (Richardson et al., 2020). By March, studies began treating infected patients with baricitinib. On 14 April 2020, it has been announced that the drug's first large randomized trial will be launched in COVID-19 patients in order to investigate the efficacy and safety of this potential treatment for patients with serious COVID-19infections (TechCrunch, 2020).

A Blood Purification System to Treat COVID-19: Another therapeutic approach is a blood purification device that filters the blood and then returns that filtered blood to the patient to reduce the number of cytokines and other inflammatory mediators which are active small proteins in the patient's bloodstream that mediate the immune response of a cell and mainly are the main cause of a "cytokine storm" that takes place in some COVID-19 patients, leading to some sort of severe inflammation, respiratory failure, rapidly progressive shock, organ failure, and death. The U.S. Food and Drug Administration (U.S Food and Drug Administration (FDA)) issued an authorization for emergency compassionate use of this blood purification device in order to treat 18-year-old or older COVID-19 patients in the (ICU) Intensive Care Unit with imminent or confirmed respiratory failure (U.S Food and Drug Administration (FDA), 2020). 


\section{COVID-19 Vaccine}

A description of the key COVID-19

vaccines under production as provided in

(Table 3). The collection is not comprehensive but represents some of the big vaccinations illustrated in client publications or records that are readily accessible, like biocentury.com (Pong, 2020).

Table 3

Types of vaccines with their description

\begin{tabular}{|c|l|}
\hline Type of vaccine & Description \\
\hline $\begin{array}{l}\text { 1. Live } \\
\text { attenuated } \\
\text { vaccines }\end{array}$ & $\begin{array}{l}\text { A live attenuated vaccine involves alive, intact bacterial cells or viruses that are handled } \\
\text { in such a manner that their pathogenicity is decreased while their immunogenicity is } \\
\text { maintained. When a viable, replicative pathogen is used, the vaccine creates significant } \\
\text { amounts of the immunogen and both the innate and adaptive weapons of the immune } \\
\text { system are rapidly activated. Also, most attenuated pathogens have both B and T epitopes } \\
\text { in such a way that adaptive responses are installed both humoral and cell-mediated. While } \\
\text { live, attenuated vaccines are usually extremely successful (Hsieh, 2014). }\end{array}$ \\
\hline $\begin{array}{l}\text { 2. Subunit } \\
\text { vaccines }\end{array}$ & $\begin{array}{l}\text { A subunit vaccine includes a pathogen-purified protein or polysaccharide producing at } \\
\text { least one defensive epitope. A significant benefit of these vaccinations is that they only } \\
\text { require a part of the virus body not the whole virus body, eliminating the chance of } \\
\text { reversal and the likelihood of side effects related to unrelated pathogenic ingredients } \\
\text { (Hsieh, 2014). }\end{array}$ \\
\hline $\begin{array}{l}\text { 3. Nucleic } \\
\text { acid } \\
\text { vaccines }\end{array}$ & $\begin{array}{l}\text { DNA vaccination includes adding pathogen-derived DNA sequences that guide the } \\
\text { production of immunogenic pathogen protein in vivo into a vaccine. The DNA vaccines } \\
\text { contain recombinant vector vaccines and vaccines with naked DNA. While several DNA } \\
\text { vaccines are now approved for pet immunizations, none of them have yet proved to be } \\
\text { appropriate for human vaccination due to low immunogenicity relative to the respective } \\
\text { protein vaccines (Hsieh, 2014). }\end{array}$ \\
\hline
\end{tabular}

\subsection{Whole Virus Vaccinations}

Or dead or Live-attenuated, whole-virus vaccinations are a popular vaccination technique. Johnson \& Johnson is one of the only multinationals embarking on COVID-19 vaccines (N. Zhang et al., 2020), according to a business newsletter; comparable to their Ebola vaccine program, they hire Janssen's AdVac ${ }^{\circledR}$ adenoviral vector and develop it in their PER.C6 ${ }^{\circledR}$ cell line development (W.-H. Chen et al., 2020; N. Zhang et al., 2020). Furthermore, researchers at Hong Kong University have developed a live influenza vaccine that produces proteins SARS-CoV-2 (W.-H. Chen et al., 2020). Eventually, Codagenix created a "codon deoptimization" technique to ameliorate viruses (Shieber, 2020) and is developing vaccine approaches for SARS-CoV-2. A significant benefit of entire virus vaccines is their innate immunogenicity and capacity to activate toll-like receptors (TLRs), like TLR 3, TLR 7/8, and TLR 9. Nonetheless, vaccinations against live viruses also need thorough external research to ensure their efficacy. It is especially a concern with coronavirus vaccines, taking into consideration the results of enhanced infectivity following immunization with live or killed entire SARS coronavirus vaccines (Jiang $\boldsymbol{e t}$ al., 2012).

\subsection{Subunit vaccinations}

Focus on eliciting an immune reaction to the spike protein (S) to prevent its docking with the host ACE2 receptor (Jiang et al., 2012). The University of Queensland is now producing viral surface proteins under sponsorship from the Coalition for Epidemic Preparedness (CEPI), to more effectively introduce them to the immune system. Also, Novavax created and produced immunogenic virus-like nanoparticles 
based on recombinant expression of the $S$-spike protein (Coleman et al., 2014) while Clover Biopharmaceuticals develops a subunit vaccine composed of a trimerized SARS-CoV-2 S protein utilizing its proprietary Trimer-Tag® technology (Clover Biopharmaceuticals, 2020), While certain full-length S-proteins often induce decreased infectivity and eosinophilic penetration with SARS. Accordingly, a group led by the Texas Children's Hospital Institute for Vaccine Production at Baylor College of Medicine (including the University of Texas Medical Branch and New York Blood Center) developed and evaluated a sub-unit vaccine composed solely of the SARS-CoV S-protein receptor-binding domain (RBD) (Chen et al., 2017; Chen et al., 2014; Jiang et al., 2012). The SARS-CoV RBD vaccine, when developed on alum, elicits elevated degrees of antioxidant immunity to the homologous virus threat. An advantage of the RBD-based vaccine is its ability to reduce host immunopotentiation (Jiang et al., 2012). Recent observations that the SARS-CoV and SARSCoV-2 RBDs show a resemblance of more than 80 percent of amino acids and bind to the same ACE2 receptor give an ability to establish any protein as a subunit (W.-H. Chen et al., 2020).
10.3. Nucleic Acid Vaccines

Several major pharmaceutical corporations have developed formulations for the vaccinations for COVID-19 nucleic acid. For example, Inovio Pharmaceuticals develops a DNA vaccine, while others follow RNA vaccine locations, such as Moderna Therapeutics and Curevac. The concept of DNA immunization began with successful experiments in mice in 1993, demonstrating protective tolerance to influenza, in 1993 But for decades, such results have not developed into equivalent human results. More recently, experimental improvements and preparations have improved the potency of nucleic acid in humans, anticipating this approach will eventually lead to the first accepted therapeutic nucleic acid vaccine (W.-H. Chen et al., 2020). 
Table 4

Major current COVID-19 vaccines development programs

\begin{tabular}{|c|c|c|}
\hline Consortium & Candidate vaccine & Reference \\
\hline \multicolumn{3}{|l|}{ Whole virus vaccines } \\
\hline 1. Janssen (Johnson \& Johnson) & $\begin{array}{l}\text { Adenovirus-vectored vaccine } \\
\text { using AdVac } ₫ \text { and PER.C6 } ® \\
\text { technology }\end{array}$ & (W.-H. Chen et al., 2020) \\
\hline 2. Codagenix/Serum Institute of India & Live-attenuated vaccine & (W.-H. Chen et al., 2020) \\
\hline \multicolumn{3}{|l|}{ Subunit vaccines } \\
\hline 1. University of Queensland/CEPI & $\begin{array}{l}\text { Protein-based vaccine using } \\
\text { Molecular Clamp platform }\end{array}$ & (James Hennessy, 2020) \\
\hline 2. Novavax & $\begin{array}{l}\text { Recombinant nanoparticle } \\
\text { technology }\end{array}$ & (W.-H. Chen et al., 2020) \\
\hline 3. Clover Bipharmaceuticals & $\begin{array}{l}\text { S-trimer recombinant protein } \\
\text { using Trimer-Tag technology }\end{array}$ & $\begin{array}{l}\text { (Clover Biopharmaceuticals, } \\
\text { 2020) }\end{array}$ \\
\hline $\begin{array}{l}\text { 4. Baylor College of Medicine, Fudan } \\
\text { University, } \\
\text { New York Blood Center, Univ Texas } \\
\text { Medical Branch }\end{array}$ & $\begin{array}{l}\text { Coronavirus RBD protein- } \\
\text { based vaccine }\end{array}$ & (W.-H. Chen et al., 2020) \\
\hline 5. Vaxart & $\begin{array}{l}\text { Oral recombinant protein } \\
\text { vaccine using VAAST } \\
\text { platform }\end{array}$ & $\begin{array}{l}\text { (W.-H. Chen et al., 2020; } \\
\text { pipelinereview.com, 2020) }\end{array}$ \\
\hline \multicolumn{3}{|l|}{ Nucleic acid vaccines } \\
\hline $\begin{array}{l}\text { 1. Inovio/Beijing Advaccine } \\
\text { Biotechnology Co./CEPI }\end{array}$ & $\begin{array}{l}\text { DNA vaccine (INO-4800, } \\
\text { based on INO-4700 MERS } \\
\text { vaccine) }\end{array}$ & (W.-H. Chen et al., 2020) \\
\hline 2. Moderna/NIH/CEPI & mRNA vaccine & (W.-H. Chen et al., 2020) \\
\hline 3. CureVac/CEPI & mRNA vaccine & (Smith, 2020) \\
\hline
\end{tabular}

\section{Conclusion}

The most important aspects right now are Early diagnosis, effective medicine, and suitable vaccine. Early diagnosis is a lifeline during this outbreak, early diagnosis will make it easier to reduce the number of the cases by scanning for those who have the virus preventing it's spreading.

\section{Conflicts of interest}

All authors declare that there is no conflict of interest.

\section{Author contribution statement}

Mohamed M. Omran, Eslam Mostafa and Aisha El-Sawah were responsible for conception and design of all the study. Ahmed Sayed provided the epidemiology statistics. Menna Mostafa and
Esraa Magdy reviewed the final manuscript. All authors drafted the manuscript, read, and approved the final version.

\section{References}

A. Hogan, C., Caya, C., et al. (2018). Rapid and simple molecular tests for the detection of respiratory syncytial virus: a review. Expert review of molecular diagnostics, 18(7), 617-629.

Agostini, M. L., Andres, E. L., et al. (2018). Coronavirus susceptibility to the antiviral remdesivir (GS-5734) is mediated by the viral polymerase and the proofreading exoribonuclease. MBio, 9(2), e00221-00218. 
Bhatraju, P. K., Ghassemieh, B. J., et al. (2020). Covid19 in Critically Ill Patients in the Seattle Region - Case Series. New England Journal of Medicine. https://doi.org/10.1056/NEJMoa2004500

Blaschke, A. J., McKevitt, M., et al. (2019). Midturbinate Swabs Are Comparable to Nasopharyngeal Swabs for Quantitative Detection of Respiratory Syncytial Virus in Infants. Journal of the Pediatric Infectious Diseases Society, 8(6), 554-558.

Cao, B., Wang, Y., et al. (2020). A trial of lopinavirritonavir in adults hospitalized with severe Covid-19. New England Journal of Medicine.

Cascella, M., Rajnik, M., et al. (2020). Features, evaluation and treatment coronavirus (COVID-19). In Statpearls [internet]. StatPearls Publishing.

CDC. (2020). Symptoms of Coronavirus. https://www.cdc.gov/coronavirus/2019ncov/about/symptoms.html

CDC. (2020). Update and Interim Guidance on Outbreak of Coronavirus Disease 2019 (COVID-19). https://emergency.cdc.gov/han/2020/han0042 $\underline{\text { 8.asp }}$

Chan, J. F.-W., Yuan, S., et al. (2020). A familial cluster of pneumonia associated with the 2019 novel coronavirus indicating person-to-person transmission: a study of a family cluster. The lancet, 395(10223), 514-523.

Chen, N., Zhou, M., et al. (2020). Epidemiological and clinical characteristics of 99 cases of 2019 novel coronavirus pneumonia in Wuhan, China: a descriptive study. The lancet, 395(10223), 507-513.
Chen, W.-H., Chag, S. M., et al. (2017). Optimization of the production process and characterization of the yeast-expressed SARS-CoV recombinant receptor-binding domain (RBD219-N1), a SARS vaccine candidate. Journal of pharmaceutical sciences, 106(8), 1961-1970.

Chen, W.-H., Du, L., et al. (2014). Yeast-expressed recombinant protein of the receptor-binding domain in SARS-CoV spike protein with deglycosylated forms as a SARS vaccine candidate. Human vaccines \& immunotherapeutics, 10(3), 648-658.

Chen, W.-H., Strych, U., et al. (2020). The SARSCoV-2 vaccine pipeline: an overview. Current tropical medicine reports, 1-4.

Chu, D. K. W., Pan, Y., et al. (2020). Molecular Diagnosis of a Novel Coronavirus (2019nCoV) Causing an Outbreak of Pneumonia. Clinical Chemistry, 66(4), 549-555. https://doi.org/10.1093/clinchem/hvaa029

Clover Biopharmaceuticals. (2020). Clover initiates development of recombinant subunit-trimer vaccine for wuhan coronavirus (2019-ncov). In.

Coleman, C. M., Liu, Y. V., et al. (2014). Purified coronavirus spike protein nanoparticles induce coronavirus neutralizing antibodies in mice. Vaccine, 32(26), 3169-3174.

Control, C. f. D., \& Prevention. (2020). Interim guidelines for collecting, handling, and testing clinical specimens from persons for coronavirus disease 2019 (COVID-19). In.

Corman, V. M., Landt, O., et al. (2020). Detection of 2019 novel coronavirus (2019-nCoV) by realtime RT-PCR. Eurosurveillance, 25(3), 2000045. 
Czub, M., Weingartl, H., et al. (2005). Evaluation of modified vaccinia virus Ankara based recombinant SARS vaccine in ferrets. Vaccine, 23(17-18), 2273-2279.

de Wit, E., van Doremalen, N., et al. (2016). SARS and MERS: recent insights into emerging coronaviruses. Nature Reviews Microbiology, 14(8), 523.

Gautret, P., Lagier, J.-C., et al. (2020). Hydroxychloroquine and azithromycin as a treatment of COVID-19: results of an openlabel non-randomized clinical trial. International journal of antimicrobial agents, 105949.

Gozes, O., Frid-Adar, M., et al. (2020). Rapid ai development cycle for the coronavirus (covid19) pandemic: Initial results for automated detection \& patient monitoring using deep learning ct image analysis. arXiv preprint arXiv:2003.05037.

Guan, W.-j., Ni, Z.-y., et al. (2020, 2020/04/30). Clinical Characteristics of Coronavirus Disease 2019 in China. New England Journal of Medicine, 382(18), 1708-1720. https://doi.org/10.1056/NEJMoa2002032

Guo, L., Ren, L., et al. (2020). Profiling early humoral response to diagnose novel coronavirus disease (COVID-19)[published online March 21, 2020]. Clin Infect Dis.

Henry, B. M., De Oliveira, M. H. S., et al. (2020). Hematologic, biochemical and immune biomarker abnormalities associated with severe illness and mortality in coronavirus disease 2019 (COVID-19): a meta-analysis. Clinical Chemistry and Laboratory Medicine (CCLM), 1(ahead-of-print).

Hsieh, F. H. (2014). Primer to the immune response. Annals of Allergy, Asthma \& Immunology, 113(3), 333.
Huang, C., Wang, Y., et al. (2020). Clinical features of patients infected with 2019 novel coronavirus in Wuhan, China. The lancet, 395(10223), 497-506.

James Hennessy. (2020). Australia's been asked to make a coronavirus vaccine at 'unprecedented speed'.

https://www.sciencealert.com/australianscientists-asked-to-make-coronavirusvaccine-at-unprecedented-speed

Jiang, S., Bottazzi, M. E., et al. (2012). Roadmap to developing a recombinant coronavirus $\mathrm{S}$ protein receptor-binding domain vaccine for severe acute respiratory syndrome. Expert review of vaccines, 11(12), 1405-1413.

Kogaki, H., Uchida, Y., et al. (2005). Novel rapid immunochromatographic test based on an enzyme immunoassay for detecting nucleocapsid antigen in SARS-associated coronavirus. Journal of clinical laboratory analysis, 19(4), 150-159.

Kong, W.-H., Li, Y., et al. (2020, 2020/05/01). SARS$\mathrm{CoV}-2$ detection in patients with influenzalike illness. Nature Microbiology, 5(5), 675678. https://doi.org/10.1038/s41564-020$\underline{0713-1}$

Leung, N. H., Chu, D. K., et al. (2020). Respiratory virus shedding in exhaled breath and efficacy of face masks. Nature medicine, 1-5.

Li, G., \& De Clercq, E. (2020). Therapeutic options for the 2019 novel coronavirus (2019-nCoV). In: Nature Publishing Group.

Li, Q., Guan, X., et al. (2020, 2020/03/26). Early Transmission Dynamics in Wuhan, China, of Novel Coronavirus-Infected Pneumonia. New England Journal of Medicine, 382(13), 11991207. https://doi.org/10.1056/NEJMoa2001316 
Li, W., Moore, M. J., et al. (2003). Angiotensinconverting enzyme 2 is a functional receptor for the SARS coronavirus. nature, 426(6965), 450-454.

Live Science. (2020). Treatments for COVID-19: Drugs being tested against the coronavirus. https://www.livescience.com/coronaviruscovid-19-treatments.html

Long, C., Xu, H., et al. (2020). Diagnosis of the Coronavirus disease (COVID-19): rRT-PCR or CT? European journal of radiology, 108961.

Lu, R., Zhao, X., et al. (2020). Genomic characterisation and epidemiology of 2019 novel coronavirus: implications for virus origins and receptor binding. The lancet, 395(10224), 565-574.

McMichael, T. M., Currie, D. W., et al. (2020). Epidemiology of Covid-19 in a Long-Term Care Facility in King County, Washington. New England Journal of Medicine. https://doi.org/10.1056/NEJMoa2005412

Mimouni, F., Lakshminrusimha, S., et al. (2020, 2020/05/01). Perinatal aspects on the covid-19 pandemic: a practical resource for perinatalneonatal specialists. Journal of Perinatology, 40(5), 820-826. https://doi.org/10.1038/s41372-020-0665-6

Mousavizadeh, L., \& Ghasemi, S. (2020). Genotype and phenotype of COVID-19: Their roles in pathogenesis. Journal of Microbiology, Immunology and Infection.

Ou, X., Liu, Y., et al. (2020, 2020/03/27). Characterization of spike glycoprotein of SARS-CoV-2 on virus entry and its immune cross-reactivity with SARS-CoV. Nature Communications, $\quad 11(1), \quad 1620$. https://doi.org/10.1038/s41467-020-15562-9
Peng, X., Xu, X., et al. (2020, 2020/03/03). Transmission routes of $2019-\mathrm{nCoV}$ and controls in dental practice. International Journal of Oral Science, 12(1), 9. https://doi.org/10.1038/s41368-020-0075-9

pipelinereview.com. (2020). Vaxart Announces Initiation of Coronavirus Vaccine Program. https://pipelinereview.com/index.php/202002 0273689/Vaccines/Vaxart-AnnouncesInitiation-of-Coronavirus-VaccineProgram.html

Pong, W. (2020). A Dozen Vaccine Programs Underway as WHO Declares Coronavirus Public Health Emergency. In: Biocentury.

Raj, V. S., Mou, H., et al. (2013). Dipeptidyl peptidase 4 is a functional receptor for the emerging human coronavirus-EMC. nature, 495(7440), 251-254.

Richardson, P., Griffin, I., et al. (2020). Baricitinib as potential treatment for 2019-nCoV acute respiratory disease. Lancet (London, England), 395(10223), e30.

Seah, I., \& Agrawal, R. (2020). Can the coronavirus disease 2019 (COVID-19) affect the eyes? A review of coronaviruses and ocular implications in humans and animals. Ocular immunology and inflammation, 28(3), 391395.

Sheridan, C. (2020). Fast, portable tests come online to curb coronavirus pandemic. Nat Biotechnol, 10.

Shieber, J. (2020). Codagenix raises \$20 million for a new flu vaccine and other therapies. Tech Crunch. In.

Smith, J. (2020). CureVac bids to develop first mRNA coronavirus vaccine. 2020 . In. 
Tai, W., He, L., et al. (2020a). Characterization of the receptor-binding domain (RBD) of 2019 novel coronavirus: implication for development of RBD protein as a viral attachment inhibitor and vaccine. Cellular \& Molecular Immunology, 1-8.

Tai, W., He, L., et al. (2020b, 2020/03/19). Characterization of the receptor-binding domain (RBD) of 2019 novel coronavirus: implication for development of RBD protein as a viral attachment inhibitor and vaccine. Cellular \& Molecular Immunology. https://doi.org/10.1038/s41423-020-0400-4

Tan, L., Wang, Q., et al. (2020, 2020/03/27). Lymphopenia predicts disease severity of COVID-19: a descriptive and predictive study. Signal Transduction and Targeted Therapy, 5(1), 33. https://doi.org/10.1038/s41392-020$0148-4$

TechCrunch. (2020). Potential new treatment for COVID-19 uncovered by BenevolentAI enters trials.

https://techcrunch.com/2020/04/14/potentialnew-treatment-for-covid-19-uncovered-bybenevolentai-enters-trials/

The Johns Hopkins Center for Health Security. (2020 ). Serology-based tests for COVID-19. https://www.centerforhealthsecurity.org/resou rces/COVID-19/serology/Serology-basedtests-for-COVID-19.html

U.S Food and Drug Administration (FDA). (2020). Emergency Use Authorization (EUA) information, and list of all current EUAs https://www.fda.gov/emergencypreparedness-and-response/mcm-legalregulatory-and-policy-framework/emergencyuse-authorization\#covidtherapeutics

Vaduganathan, M., Vardeny, O., et al. (2020). ReninAngiotensin-Aldosterone System Inhibitors in Patients with Covid-19. New England Journal of Medicine, 382(17), 1653-1659. https://doi.org/10.1056/NEJMsr2005760

van Boheemen, S., de Graaf, M., et al. (2012). Genomic characterization of a newly discovered coronavirus associated with acute respiratory distress syndrome in humans. MBio, 3(6), e00473-00412.

Vandenberg, O. (2020). Development and potential usefulness of the COVID-19 Ag Respi-Strip diagnostic assay in a pandemic context. medRxiv.

Vincent, M. J., Bergeron, E., et al. (2005). Chloroquine is a potent inhibitor of SARS coronavirus infection and spread. Virology journal, 2(1), 69.

Wang, D., Hu, B., et al. (2020). Clinical characteristics of 138 hospitalized patients with 2019 novel coronavirus-infected pneumonia in Wuhan, China. Jama, 323(11), 1061-1069.

Wang, H., Wang, Z., et al. (2020, 2020/02/24). Phaseadjusted estimation of the number of Coronavirus Disease 2019 cases in Wuhan, China. Cell Discovery, 6(1), 10. https://doi.org/10.1038/s41421-020-0148-0

Wang, S., Kang, B., et al. (2020). A deep learning algorithm using CT images to screen for Corona Virus Disease (COVID-19). medRxiv.

Wang, W., Xu, Y., et al. (2020). Detection of SARS$\mathrm{CoV}-2$ in different types of clinical specimens. Jama, 323(18), 1843-1844.

Whitworth, J. (2020). COVID-19: a fast evolving pandemic. Transactions of The Royal Society of Tropical Medicine and Hygiene, 114(4), 241.

WHO. (2019). Middle East respiratory syndrome coronavirus

(MERS-CoV). 
https://www.who.int/emergencies/merscov/en/

WHO. (2020a). Coronavirus disease 2019 (COVID19): situation report, 26.

WHO. (2020b). Coronavirus disease 2019 (COVID19): situation report, 37.

WHO. (2020c). Coronavirus disease 2019 (COVID19): situation report, 38.

WHO. (2020d). Coronavirus disease 2019 (COVID19): situation report, 39.

WHO. (2020e). Coronavirus disease 2019 (COVID19): situation report, 40.

WHO. (2020f). Coronavirus disease 2019 (COVID19): situation report, 41.

WHO. (2020g). Coronavirus disease 2019 (COVID19): situation report, 42.

WHO. (2020h). Coronavirus disease 2019 (COVID19): situation report, 48.

WHO. (2020i). Coronavirus disease 2019 (COVID19): situation report, 51.

WHO. (2020j). Coronavirus disease 2019 (COVID19): situation report, 52.

WHO. (2020k). Coronavirus disease 2019 (COVID19): situation report, 55

WHO. (20201). Coronavirus disease 2019 (COVID19): situation report, 58 .

WHO. (2020m). Coronavirus disease 2019 (COVID19): situation report, 61.
WHO. (2020n). Coronavirus disease 2019 (COVID19): situation report, 65.

WHO. (2020o). Coronavirus disease 2019 (COVID19): situation report, 68 .

WHO. (2020p). Coronavirus disease 2019 (COVID19): situation report, 71 .

WHO. (2020q). Coronavirus disease 2019 (COVID19): situation report, 76 .

WHO. (2020r). Coronavirus disease 2019 (COVID19): situation report, 81 .

WHO. (2020s). Coronavirus disease 2019 (COVID19): situation report, 86 .

WHO. (2020t). Coronavirus disease 2019 (COVID19): situation report, 91.

WHO. (2020u). Coronavirus disease 2019 (COVID19): situation report, 101.

WHO. (2020v). Novel Coronavirus ( 2019-nCoV): situation report, 3 .

WHO. (2020w). Novel Coronavirus ( 2019-nCoV): situation report, 6 .

WHO. (2020x). Novel Coronavirus ( 2019-nCoV): situation report, 9 .

WHO. (2020y). Novel Coronavirus ( 2019-nCoV): situation report, 11.

WHO. (2020z). Novel Coronavirus ( 2019-nCoV): situation report, 12 . 
Woo, P. C., Huang, Y., et al. (2010). Coronavirus genomics and bioinformatics analysis. viruses, 2(8), 1804-1820.

Xia, S., Liu, M., et al. (2020, 2020/04/01). Inhibition of SARS-CoV-2 (previously 2019$\mathrm{nCoV}$ ) infection by a highly potent pancoronavirus fusion inhibitor targeting its spike protein that harbors a high capacity to mediate membrane fusion. Cell Research, 30(4), 343355. https://doi.org/10.1038/s41422-0200305-x

Xu, H., Zhong, L., et al. (2020, 2020/02/24). High expression of ACE2 receptor of 2019-nCoV on the epithelial cells of oral mucosa. International Journal of Oral Science, 12(1), 8. https://doi.org/10.1038/s41368-020-0074-X

Yan, R., Zhang, Y., et al. (2020). Structural basis for the recognition of SARS-CoV-2 by full-length human ACE2. Science, 367(6485), 1444. https://doi.org/10.1126/science.abb2762

Zhang, F., Abudayyeh, O. O., et al. (2020). A protocol for detection of COVID-19 using CRISPR diagnostics. A protocol for detection of COVID-19 using CRISPR diagnostics, 8.

Zhang, N., Li, C., et al. (2020). Current development of COVID-19 diagnostics, vaccines and therapeutics. Microbes and Infection.

Zhang, Y. (2020). Novel 2019 coronavirus genome. Virological. In.

Zhou, P., Yang, X.-L., et al. (2020). A pneumonia outbreak associated with a new coronavirus of probable bat origin. nature, 579(7798), 270273.

Zhu, N., Zhang, D., et al. (2020). A novel coronavirus from patients with pneumonia in China, 2019. New England Journal of Medicine.
Zou, L., Ruan, F., et al. (2020). SARS-CoV-2 viral load in upper respiratory specimens of infected patients. New England Journal of Medicine, 382(12), 1177-1179. 